Saudi Journal of Medical and Pharmaceutical Sciences

Abbreviated Key Title: Saudi J Med Pharm Sci

ISSN 2413-4929 (Print) |ISSN 2413-4910 (Online)

Scholars Middle East Publishers, Dubai, United Arab Emirates

Journal homepage: https://saudijournals.com

Review Article

\title{
Nanoethosomes: A Novel Revolutionary Approach for Transdermal Drug Delivery
}

\author{
Ghazala Javeriya Surdana ${ }^{*}$ K. Arshad Ahmed Khan, P. Ravi Prakash, N. Vijaya Bhaskar \\ Department of Pharmaceutics, C.E.S College of Pharmacy, Kurnool, Andhra Pradesh, India-518218
}

\author{
DOI: $10.36348 /$ sjmps.2021.v07i02.004 $\quad$ | Received: 21.01 .2021 | Accepted: 06.02.2021 | Published: 11.02 .2021 \\ *Corresponding author: Ghazala Javeriya Surdana
}

\section{Abstract}

In current scenario transdermal delivery of bioactive molecules has become an interesting research area. Transdermal delivery enables direct entry of bioactive molecules into systemic circulation, bypass of hepatic metabolism, improves patient compliance, and low risk of injury to the tissues. Though it is one of the attractive routes, transport of drug through the skin has remained a challenge. To overcome the challenge, vesicular system has been adopted so as to have better skin permeation of bioactive agents. Vesicular system like liposome has shown inefficiency to cross the layers of skin. To overcome this hurdle a novel vesicular \& non-invasive drug delivery system Nanoethosomes was developed. Nanoethosomes are used for deeper permeation of bioactive molecules. The main components are phospholipids, ethanol, and water. Presence of high amount of ethanol in their structure differentiates them from other vesicular systems and also helps to release encapsulated material into basal skin layer and blood circulation. Ethanol gives a net negative charge on vesicle surface promoting its size reduction. Vesicular system gives a better patient compliance, being a non-invasive method of drug administration. In this review article we are going to see brief information about methods of preparation, characterization and pharmaceutical uses of Nanoethosomes.

Keywords: Nanoethosomes, Phospholipid, Transdermal, Non-Invasive method, Vesicular system, Ethanol.

Copyright () 2021 The Author(s): This is an open-access article distributed under the terms of the Creative Commons Attribution 4.0 International License (CC BY-NC 4.0) which permits unrestricted use, distribution, and reproduction in any medium for non-commercial use provided the original author and source are credited.

\section{INTRODUCTION}

In last few decades many significant advancements in the field of drug delivery technology have been made. This advancement took place as there was no remarkable growth in developing new drug entities. Drug delivery emerged as a branch of science which comprises of bio pharmaceutics and pharmacokinetics. Drug delivery enhances the efficacy of drugs through controlled release by considering the factors like carrier system, route of administration and target of drug action. Drug delivery system improves patient compliance, therapeutic index and bioavailability [1].

In current scenario transdermal delivery of bioactive molecules has become an interesting research area; however, effective transdermal drug delivery is still a challenge. Various approaches explored for transdermal delivery which overcome barrier functions of skin include electrically assisted methods (sonophoresis, iontophoresis, and electrophoresis), micro-invasive techniques, vesicular systems, and use of chemical permeation enhancers. Transdermal delivery enables direct entry of bioactive molecules into systemic circulation, bypass of hepatic metabolism, improvement of patient compliance, and low risk of injury to the tissues.

A bioactive molecule should have characteristics like low molecular weight $(<500 \mathrm{Da})$, high pharmacological activity, high effectiveness at low doses (5-10 mg/day), and high lipophilicity for achievement of good results following transdermal administration. Various classes of drugs fulfilling these criterions are analgesics, contraceptives, antianginals, and antihypertensive drugs. Vesicular system is most widely investigated approach for transdermal drug delivery.

Vesicles are colloidal systems in which hydrophilic core is surrounded by amphiphilic molecules in a Double layered fashion. Vesicular systems have capability to encapsulate wide variety of drug via hydrophilic, lipophilic, charged hydrophilic, and amphiphilic drugs. Effectiveness of a vesicular system as a carrier depends on various physicochemical characteristics like surface charge, size, elasticity, thermodynamic phase, and lamellarity.

\section{Nanoethosomes}

Nanoethosomes are nanosized lipid based vesicular carriers having high concentration of ethanol 
Ghazala Javeriya Surdana et al., Saudi J Med Pharm Sci, Feb, 2021; 7(2): 91-101

used for deeper skin permeation of bioactive molecules. The main components of Nanoethosomes are phospholipids, ethanol, and water. Presence of high amount of ethanol in their structure differentiates them from other vesicular systems and also helps to release encapsulated material into basal skin layer and blood circulation. First time development of ethosomes was carried out by Touitou in 1996 for skin permeation enhancement. Fig-1 gives structural elucidation of nanoethosomes. Water and ethanol with drug molecule reside as a core in Phospholipid bilayer, some amount of ethanol can occupy bilayered region also. Nanoethosomes are soft and malleable in nature. Size of Nanoethosomes lies in nanometer range; although, it is dependent on phospholipid concentration used. High alcohol content in Nanoethosomes may be another factor for their reduced size compared to liposomes prepared under same conditions. Ethanol gives a net negative charge on vesicle surface promoting its size reduction. Nanoethosomes penetrate through intercellular pathway in the stratum corneum as depicted in Fig-2. Fluidization caused by ethanol increases the intracellular space between corneocytes [2].
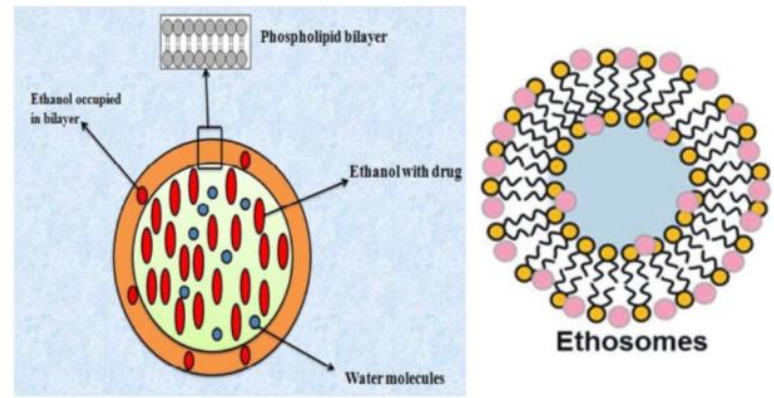

Fig-1: Schematic structure of Nanoethosomal system

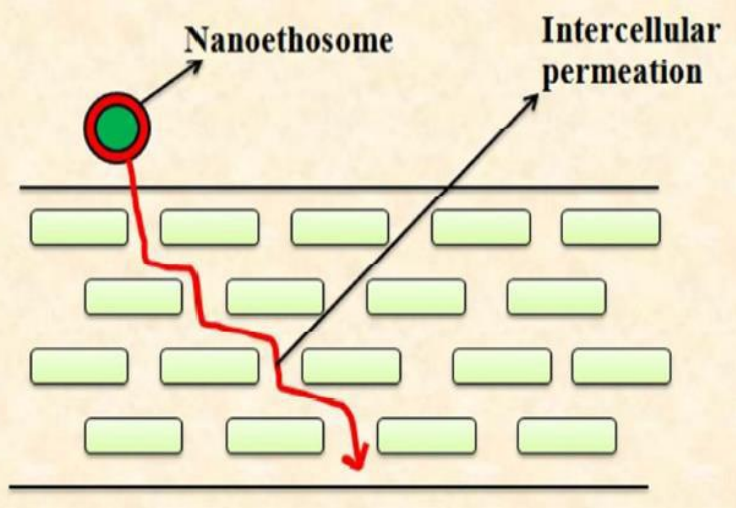

Fig-2: Intracellular permeation of Nanoethosomes in skin

Advantages and disadvantages of vesicular carriers

- Many vesicular formulations for drug administration through parenteral, topical as well as oral route have been developed.

- Vesicular drugs provide advantages like safer \& convenient way of drug administration and most importantly it provides a protection for the active constituent in in-vivo condition from premature degradation. In addition, vesicular carriers make it possible to release encapsulated molecule in sustained and controlled manner. Due to this pattern of release it becomes easy to ensure targeted delivery of drug to the target tissues.

- Challenges like pre-systemic metabolism, frequent dosing, and variation in GI absorption of drug can be overcome by vesicular carriers. Vesicular carriers reduce the dosing frequency due to which the cost to the patient decreases and ensures better patient compliance.

- Vesicular carrier increases the bioavailability as it enhances the permeation of drug through biological carriers.

- Only disadvantage associated with vesicular carrier is that few patients reported symptoms of dermatitis [1].

\section{Advantages of Nanoethosomes}

- Nanoethosomes as a carrier makes it possible to deliver large molecules like proteins.

- The material used to prepare Nanoethosomes is non-toxic, so it is not at all harmful for the recipient [1].

- Nanoethosomes are biodegradable in nature and high alcohol content gives a negative charge to them restricting their vesicular size low; leading to high penetration and enhanced bioavailability of bioactive molecules.

- Nanoethosomes show high encapsulation efficiency for wide variety of molecules including lipophilic drugs.

- Drug loaded Nanoethosomes can be easily dispersed in cream or gel; therefore, providing high patient compliance compared to electrically assisted techniques like iontophoresis [2].

\section{Disadvantages of Nanoethosomes}

- It does not provide a rapid bolus drug input. To gain entry into blood circulation the drug has to be soluble in both lipophilic and aqueous phase.

- Adhesives used in Nanoethosomes may not adhere on the skin of every single patient.

- A particular molecular size of drug can be can be delivered by this system. It may not be economical for certain segment of patients [1].

\section{Various formulation ingredients of Nanoethosomes} and their role

- Nanoethosomes have phospholipids, ethanol, and water as main formulation ingredients.

- Phospholipids have an integral role in bilayer formation; consisting of hydrophilic head and hydrophobic tail.

- Commonly used phospholipids in nanoethosomes manufacturing are phosphatidylcholine (PC), 
soybean phosphatidylcholine (Phospholipon 90), and phosphatidylethanolamine (PE).

- Alcohol is a central character of nanoethosomal system giving unique identity to it as a vesicular system.

- $\quad$ Lipidic layer of stratum corneum are fluidized by impact of ethanol and its high concentration in Nanoethosomes promote malleability and flexibility of these systems promoting their penetration through tiny openings formed in stratum corneum due to fluidization.

- Alcohol amount in vesicular system also control its diameter as it provides net negative charge to vesicle surface reducing its size.

- $\quad 30-40 \%$ is optimum concentration range of ethanol for the formation of stable ethosomes; Reducing ethanol concentration to $20 \%$ may leads to increase in vesicular size.

- Skin permeation enhancers like transcutol and polyols (propylene glycol) are also used for nanoethosome formulation.

- Permanence of ethosomal membrane is maintained by adding small amount of cholesterol [2].

\section{Penetration mechanisms for ethanol-based vesicular carriers}

\section{a) Ethanol effect on skin}

Nanoethosomes contains around $20-50 \%$ of ethanol. The action of ethanol on the lipid layer is shown in Figure-3 with comparison to the lipid layer where there is no ethanol present. Figure-3B is showing void space is created and filled with ethanol that in turn increased area per lipid molecule. X-ray diffraction shows that the lipid bilayer has interdigitated Membrane leaflet which eventually leads to thinner membrane when ethanol comes in contact with the lipid bilayer. As the surface density of lipid decreases the bilayer gets thinner which leads to membrane distention. Due to presence of alcohol at the surface the change in membrane shape get accelerated, experimentally it has proved that Alcohol promotes fusion of discontinuous membrane by breaking the single layer continuity. The result that comes up from this demonstration is that presence of ethanol can bring about alteration in rate of change in shape by membrane in an exocytosis manner. In this mechanism the concentration of alcohol is quite higher as compared to that which is found in the blood in case of intoxication. Ethanol accumulate in some region of body such as striatum, Brain to an extent of three times of the level that is found in blood. Clearance from alcohol from striatum is relatively slower as compared to other region of body [1].
A
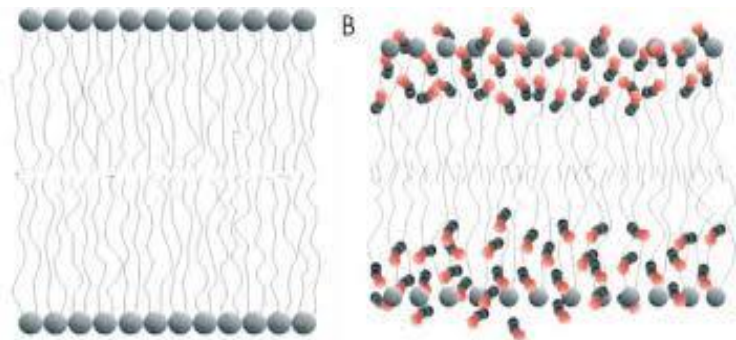

Fig-3: Schematic representation of ethanol's presence and absence on the bilayer lipid membrane: (A)

Representation of bilayer lipid membrane structure in the absence of ethanol; (B) Presence of ethanol molecule is being represented as gray and red dots in the lipid bilayer membrane which partition into glycerol backbone and a hydrophilic head resulting in an increase in area per lipid molecule

\section{b) Mechanism of skin penetration through vesicular carrier}

Vesicular system assists in transdermal drug delivery of molecule either by enhancing penetration of free drug component or permeation is enhanced by the component of vesicles as shown in Fig-4. In some cases, the transdermal drug delivery takes place by intact vesicle penetration into the skin and then through it. Vesicle get adsorb and fused with the stratum and assist the transdermal drug delivery. Ethanol a component in ethosomes and nanoethosomes act as a great permeation enhancer as it fluidizes membranous lipid bilayer along with the lipid present in stratum Corneum. Stratum corneum composed of compactly packed phospholipid, when ethanol comes in contact with it disrupts the compact packing of phospholipid and fluidizes the lipid layer. This fluidization of lipid layer is the mechanism through which drug delivery by nanoethosomes occurs. An investigation is carried out by M.M.A Elsayed et al., to prove that the basic mechanism of skin delivery of drug is enhancement of permeation by ethanol and flexible nature of vesicles. The investigation focused on the in-vitro profile of drug outside the vesicles, drug inside the vesicle and drug on both side of vesicle. Out of the four the formulations the drug which was present inside the vesicular carrier displayed enhanced permeation then the remaining two formulations. From this it can be concluded that presence of ethanol is not major factor of permeation, if it would have been the case then drug outside the vesicle would have shown better permeation.

This also suggests that the deformable nature of vesicle assist in enhanced penetration and drug delivery of drug. Godin and Touitou proved vesicle adsorption to the skin and fusion of vesicular layer with stratum corneum of skin. It is observed that the drug present in liposomal preparation is unable to penetrate into skin although the preparation gets adsorbed to the membrane. In case of ethosomal preparation the ethanol present in it gets intercalated on lipid present in stratum corneum which results in increase in membrane permeability. Ethosomes are flexible and after fusion 
with the membrane they successfully deliver the drug inside the cells. The presence of ethanol and edge activator in vesicles enhances its flexibility and fluidity and due this kind of elastic nature, vesicles can easily pass through narrow intercellular pathway [1].
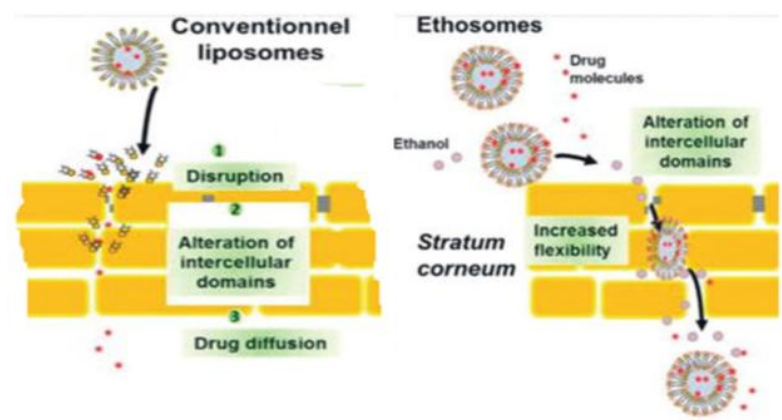

Fig-4: Schematic representation of permeation mechanisms of lipid-based vesicles

\section{Methods of Nanoethosomes preparation:}

There are four methods of preparation for Nanoethosomes.

\section{a) Cold technique}

This technique is most widely used of preparation of Nanoethosomes. This method involves dissolvation of lipidic materials in ethanol with continuous stirring at room temperature followed by the addition polyol solution and heating up to $30{ }^{\circ} \mathrm{C}$ with vigorous agitation. Mixture is stirred for 5 minutes in a covered vessel. Furthermore, sonication is done to decrease the size of Nanoethosomes [2].

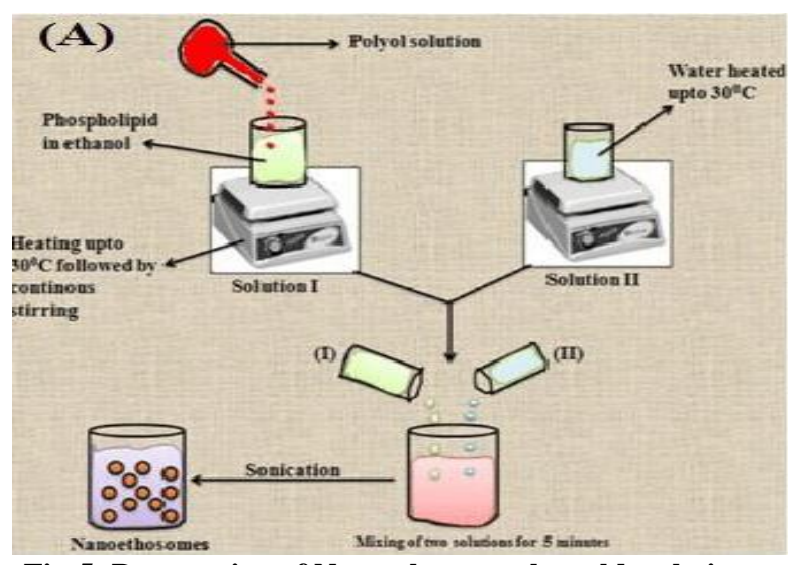

Fig-5: Preparation of Nanoethosomes by cold techniques

\section{b) Hot Technique}

In this technique phospholipid is dispersed in water and heated up to $40{ }^{\circ} \mathrm{C}$ for the formation of colloidal dispersion. Furthermore, mixture of polyol and ethanol are heated up to $40{ }^{\circ} \mathrm{C}$ in a separate container. Both solutions are then mixed with each other by continuous stirring depending upon hydrophilic or lipophilic nature of drug; it is either dissolved in water or ethanol. Probe sonication of mixture is carried out later on to get Nanoethosomes of desired size [2].

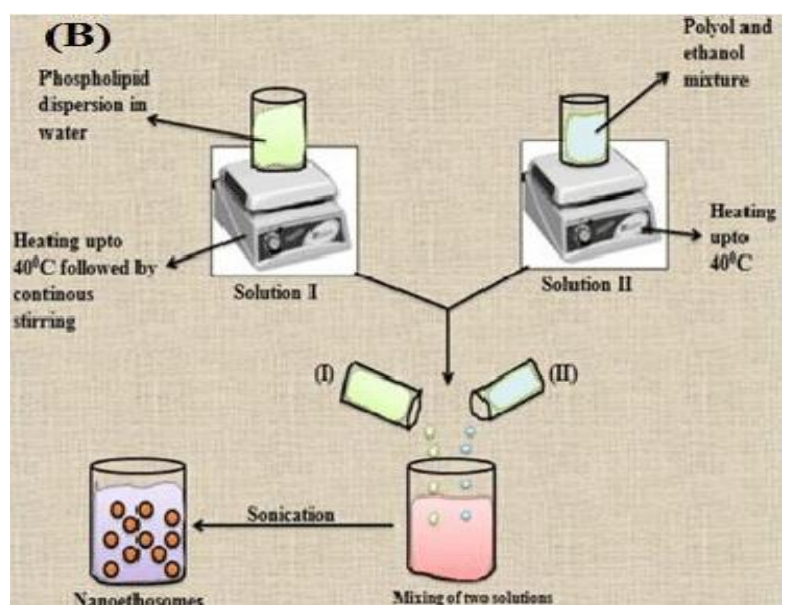

Fig-6: Preparation of Nanoethosomes by hot technique

\section{c) Preparation by classical method}

In this method, a mixture of ethanol, active medicaments and phospholipid is taken in such way that the active medicament and phospholipid get dissolved in ethanol. Then the solution mixture is heated by using a water bath at a temperature of about $30+1{ }^{\circ} \mathrm{C}$. In the next step to solution mixture double distilled water is added with continuous stirring at a speed of $700 \mathrm{rpm}$. Then with the help of hand extruder, the obtained vesicles are homogenized for three cycles using polycarbonate membrane [1].

\section{d) Preparation by mechanical dispersion method}

In this method a mixture of chloroform and ethanol is taken in a round bottom flask (RBF). To the round bottom flask soya phosphatidylcholine is added and made to dissolve in the chloroform and ethanol mixture. By using rotary vacuum evaporator organic solvent is removed. This step is carried out at a temperature that is above the lipid transition temperature. The main purpose of maintaining that temperature is that at the said temperature a thin lipid film gets deposited on the surface of a round bottom flask. Then the round bottom flask is kept overnight so that trace of solvent can be obtained from the lipid film that got deposited on the round bottom flask. Then hydro ethanol hydration is being done by simply rotating round bottom flask at the required temperature by employing different concentration of drug mixture [1].

\section{Evaluation parameters of vesicular carriers Morphology of Nanoethosomes}

Morphology defined as study of shape and size of vesicular carriers. Generally vesicular carriers are regular spherical in shape and they are physically soft and flexible and core is enclosed. With the help of microscope morphology of vesicular carrier is studied. Morphology of nanoethosomes can be studied by using scanning electron Microscopy (SEM) and transmission 
electron microscopy (TEM). TEM involves drying of samples on carbon coated grid and negative staining with aqueous solution of phosphotungstic acid. Furthermore, samples are dried and observed under high magnification at an accelerating voltage of 100 $\mathrm{kV}$. SEM involves mounting of ethosomal solution on clear glass stub, air drying, and coating with Polaron E 5100 Sputter coater, and visualization under microscope. In addition to identification study, morphology also explains the detection the pattern of packing of particles and aggregation $[1,2]$.

\section{Particle size and size distribution}

Vesicle size and size distribution of nanoethosomes can be determined by using dynamic light scattering (DLS) technique. For DLS investigations; mixing of nanoethosomal suspension is carried out with appropriate medium [usually phosphate buffer saline (PBS)]. Nanosizers are employed to measure the size and size distribution of vesicular carriers. Photon correlation spectroscopy is also used for determination of particle size $[1,2]$.

\section{Zeta Potential}

Zeta potential can be defined as the degree of electrostatic repulsion and attraction in colloidal dispersion. Distribution of charge on the surface of vesicular carrier is expressed by zeta potential. The presence of charge on the surface of nanoparticle is a major determinant of stability of the product. The presence of negative and positive charge on vesicular carrier depends upon the excipient used in the formulation. Zeta potential provides information regarding every component of formulation and interaction among them and also information regarding surface chemistry. Zeta potential is determining factor for stability of colloidal dispersion system. It also determines the interaction between vesicles and membrane [1].

\section{Drug Content}

To know whether the preparation content the required active ingredient in required amount in the vesicles, the vesicles are lysed so that the content is released. The released content is put into the solution then the solution is subjected to spectrophotometric analysis or chromatographic assay. Lysis of vesicles is done by solvents like isopropyl alcohol, methanol etc. [1].

\section{Encapsulation Efficiency}

Encapsulation efficiency of nanoethosomes can be determined by using ultracentrifugation or dialysis bag method. It is calculated by using formula given below:

Where,

$$
\text { Encapsulation Efficiency }=\frac{\mathrm{W} 1-\mathrm{W} 2}{\mathrm{~W} 1} \mathrm{X} 100
$$

W1- Theoretical amount of drug added

W2- Amount of drug detected in supernatant

\section{a) Ultracentrifugation}

In this method, prepared nanoethosomal formulation is kept overnight and then subjected to ultracentrifugation at specific RPM for calculated period of time. Samples are assayed using highperformance liquid chromatography [2].

\section{b) Dialysis bag method}

In this method dialysis bag made up of cellulose acetate are used for the study. Bags are kept in saline solution for $1 \mathrm{hr}$ prior to use for wetting of membrane. A specific amount of drug loaded vesicles are then placed into dialysis bag following its transfer to phosphate buffer saline $(500 \mathrm{~mL})$ of a specific $\mathrm{pH}$. Receiver medium is subjected to continuous magnetic stirring. Samples withdrawn from receiver at regular time interval are analyzed by using HPLC.

\section{Permeation studies of Nanoethosomes}

Ethanol is a well-established permeation enhancer. High permeation of Nanoethosomes in skin may be due to synergistic effect of ethanol and vesicular lipids. Human cadaver skin from abdominal areas, rat skin, or guinea pig skin may be a choice to carry out permeation studies. After selecting, skin is mounted on the Franz diffusion cell along with subcutaneous side facing towards donor compartment. Near about $5 \mathrm{~mL}$ of PBS (pH 5.4) is localised in receptor compartment and subjected to magnetic stirring at 100 RPM. $100 \mu \mathrm{L}$ nanoethosomal formulations are applied to donor compartment of Franz diffusion cell maintained at $32{ }^{\circ} \mathrm{C} \pm 1{ }^{\circ} \mathrm{C}$. Samples withdrawn at specific time intervals are analysed using HPLC [2].

\section{Stability}

Stability study of Nanoethosomes is performed by monitoring size, morphology, and drug leakage after its storage at a specific temperature for specified time period. For the purpose, Nanoethosomes are kept in sealed vials of $10 \mathrm{ml}$ capacity after flushing with nitrogen.

\section{Calorimetric Analysis}

Calorimetric analysis of Nanoethosomes is carried out to determine the transition temperature (Tm) of vesicular lipids in them. Low Tm value Indicates fluidizing effect of ethanol on phospholipid bilayer. Differential scanning calorimetry (DSC) is carried out with a programmed heating rate of $10{ }^{\circ} \mathrm{C}$ per minute under a constant stream of nitrogen in range of $50{ }^{\circ} \mathrm{C}$ to $50{ }^{\circ} \mathrm{C}[2]$.

\section{Applications of Nanoethosomes \\ a) Delivery of anti-fungal drugs:}

Bhalaria et al., prepared fluconazole loaded nanoethosomes and evaluated their clinical efficacy in patients with cutaneous candidiasis. At the optimized size $(144 \pm 6.8 \mathrm{~nm})$ and entrapment $(82.68 \%)$; 
Ghazala Javeriya Surdana et al., Saudi J Med Pharm Sci, Feb, 2021; 7(2): 91-101

ethosomes showed high clinical efficacy compared to liposomal formulation, marketed formulation and hydroethanolic solution of the drug. Furthermore, the transdermal efficacy of cilcopiroxolamine loaded ethosomes was evaluated by Girhepunje et al.,
Formulation having $45 \%$ ethanol content showed highest entrapment $(72.81 \pm 3.5 \%)$ and optimized size $(152 \pm 11 \mathrm{~nm})$. Results of CLSM study revealed permeation of ethosomes up to $168 \mu \mathrm{m}$ in the rat skin [2].

Table-1: Research investigations performed over nanoethosomes for delivery of antifungal drugs

\begin{tabular}{|c|c|c|c|c|}
\hline Drug & Excipients & $\begin{array}{l}\text { Sophisticated } \\
\text { techniques used }\end{array}$ & Key findings & Author \\
\hline Clotrimazole & $\begin{array}{l}\text { Soybean } \\
\text { phosphatidyl } \\
\text { choline } \\
\text { (Phospholipon } 90 \\
\text { (H), ethanol }\end{array}$ & $\begin{array}{l}\text { TEM, Atomic force } \\
\text { microscopy } \\
\text { FT-IR spectroscopy }\end{array}$ & $\begin{array}{l}\text { Nanoethosomes showed high drug } \\
\text { entrapment, enhanced transdermal } \\
\text { permeation flux, and in-vitro } \\
\text { antifungal activity compared to } \\
\text { ultra-deformable liposomes; along } \\
\text { with high zone of inhibition } \\
\text { compared to marketed formulation }\end{array}$ & $\begin{array}{l}\text { Maheshwari RG } \\
\text { et al., [3] }\end{array}$ \\
\hline $\begin{array}{l}\text { Econazole } \\
\text { nitrate }(\mathrm{EN})\end{array}$ & $\begin{array}{l}\text { Soya } \\
\text { phosphatidylcholine, } \\
\text { Ethanol, Cholesterol }\end{array}$ & $\begin{array}{l}\text { TEM, HPLC, } \\
\text { Confocal Laser } \\
\text { Scanning } \\
\text { Microscopy } \\
\text { (CLSM). }\end{array}$ & $\begin{array}{l}\text { Optimized nanoethosomal gel } \\
\text { showed controlled release for } 12 \mathrm{~h} \text {, } \\
\text { two folds higher diffusion across } \\
\text { rat skin, and high stability } \\
\text { compared to liposomal and } \\
\text { hydroethanolic gels }\end{array}$ & $\begin{array}{l}\text { Verma P et al., } \\
\text { [4] }\end{array}$ \\
\hline Clotrimazole & $\begin{array}{l}\text { Cavamax (W6, W7, } \\
\text { and W8), propylene } \\
\text { glycol, Ethanol, } \\
\text { triethanolamine, } \\
\text { iso-propyl myristate }\end{array}$ & TEM, CLSM. & $\begin{array}{l}\text { Cavamax W7 composite ethosomal } \\
\text { gel showed high drug permeation } \\
\text { flux, deeper penetration in } \\
\text { epidermis, and high antifungal } \\
\text { activity against Candida albicans } \\
\text { and Aspergillus niger compared to } \\
\text { normal ethosomal gel }\end{array}$ & $\begin{array}{l}\text { Akhtar N, et al., } \\
{[5]}\end{array}$ \\
\hline
\end{tabular}

\section{b) Delivery of Anti-Inflammatory Drugs}

Paolino et al., prepared ammonium glycyrrhizinate loaded ethosomes and investigated antiinflammatory activity in human volunteers. Ethosomal suspension with high ethanol content $(45 \% \mathrm{v} / \mathrm{v})$ and low lecithin content $(2 \% \mathrm{w} / \mathrm{v})$ showed high in-vitro percutaneous permeation, good skin tolerability, and invivo anti-inflammatory activity in humans. Later on, Zhaowu et al., prepared matrine loaded nanoethosomes and investigated their percutaneous permeation capacity in-vitro and anti-inflammatory activity in-vivo. Nanoethosomes showed decrease in size with an increase in ethanol content; while an entrapment efficiency, increase within the increase in concentration of ethanol and phospholipid both. Matrine loaded nanoethosomes more effectively reduced induced erythema and inflammation in rat skin compared to nanoethosomal formulations.

Table-2: Role of nanoethosomes in effective transdermal delivery of other anti-inflammatory drugs

\begin{tabular}{|c|c|c|c|c|}
\hline Drug & Excipients & $\begin{array}{l}\text { Sophisticated } \\
\text { techniques used }\end{array}$ & Key findings & Author \\
\hline Triptolide & $\begin{array}{l}\text { Dipalmitoyl } \\
\text { phosphatidyl } \\
\text { choline, cholesterol, } \\
\text { ethanol }\end{array}$ & HPLC & $\begin{array}{l}\text { Nanoethosomal formulation showed } \\
\text { highest in-vitro accumulation of } \\
\text { Triptolide in skin and significant } \\
\text { reduction in erythema in-vivo in rat } \\
\text { model }\end{array}$ & $\begin{array}{l}\text { Chen JG, et al., } \\
{[6]}\end{array}$ \\
\hline Ketoproen & $\begin{array}{l}\text { Soya phosphatidyl } \\
\text { choline, cholesterol, } \\
\text { ethanol }\end{array}$ & TEM, CLSM, HPLC & $\begin{array}{l}\text { Nanoethosomal formulation showed } \\
\text { high transdermal flux and high in- } \\
\text { vitro penetration compared to } \\
\text { hydroethanolic solution of drug } \\
\text { through human skin }\end{array}$ & $\begin{array}{l}\text { Chourasia MK et } \\
\text { al., [7] }\end{array}$ \\
\hline Diclofenac & $\begin{array}{l}\text { Phosphatidylcholine, } \\
\text { phosphatidylethanola } \\
\text { mine, Diethylene } \\
\text { glycol, cholesterol, } \\
\text { ethanol }\end{array}$ & $\begin{array}{l}\text { TEM, X-ray } \\
\text { diffraction } \\
\text { (small and wide angle } \\
\text { X-ray scattering } \\
\text { SAXS } \\
\text { and WAXS), HPLC }\end{array}$ & $\begin{array}{l}\text { Results of in vivo and ex vivo showed } \\
\text { capability of all vesicular systems } \\
\text { especially PEVs (penetration } \\
\text { enhancer containing vesicles) to } \\
\text { localize drug at inflammation site } \\
\text { compared to marketed formulation } \\
\text { (Voltaren) in mice skin }\end{array}$ & $\begin{array}{l}\text { Caddeo C et al., } \\
{[8]}\end{array}$ \\
\hline
\end{tabular}




\section{c) Delivery of Cardiovascular Drugs}

Touitou et al., investigated minoxidil loaded nanoethosomes for transdermal delivery. Prepared nanoethosomal formulation at $2 \%$ phosphatidylcholine and $30 \%$ ethanol showed rapid enhancement in transdermal permeability of compared hydroethanolic or phospholipid ethanolic solution of minoxidil. Furthermore, Ahad et al., investigated skin penetration capacity of valsartan loaded nanoethosomes using CLSM and pharmacokinetic behavior in Wistar albino rats. Results of study showed penetration of nanoethosomes in deeper skin layers compared to conventional liposomes and 3.03 times increase in bioavailability compared to oral suspension of valsartan. Later on, preclinical evaluation of valsartan loaded nanoethosomes was carried out by Bhosale and Avachat in wistar albino rats. Nanoethosomes showed a prolonged antihypertensive effect in wistar rats following transdermal application compared to orally administered drug suspension. Histopathological investigation showed dissolvation of intercellular lipids of epidermis by nanoethosomes promoting their high penetration.

Table-3: Nanoethosomes for transdermal delivery of cardiovascular drugs

\begin{tabular}{|l|l|l|l|l|}
\hline Drug & Exicipient & $\begin{array}{l}\text { Sophisticated } \\
\text { techniques used }\end{array}$ & Key findings & Author \\
\hline Minoxidil & $\begin{array}{l}\text { Phospholipon 90, } \\
\text { ethanol, } \\
\text { Phosphotungstic } \\
\text { acid }\end{array}$ & $\begin{array}{l}\text { TEM, CLSM, } \\
\text { HPLC, 31P-NMR }\end{array}$ & $\begin{array}{l}\text { Prepared nanoethosomal formulation at 2\% } \\
\text { phosphatidylcholine and 30\% ethanol showed } \\
\text { rapid enhancement in transdermal } \\
\text { permeability of compared hydroethanolic or } \\
\text { phospholipid ethanolic solution of minoxidil }\end{array}$ & $\begin{array}{l}\text { Touitou. } \\
\text { E } \text { al., [9] }\end{array}$ \\
\hline Valsartan & $\begin{array}{l}\text { Phospholipon 90G, } \\
\text { ethanol, Cholesterol }\end{array}$ & $\begin{array}{l}\text { TEM, CLSM, } \\
\text { HPLC }\end{array}$ & $\begin{array}{l}\text { Results of study showed penetration of } \\
\text { nanoethosomes in deeper skin layers } \\
\text { compared to conventional liposomes and 3.03 } \\
\text { times increase in bioavailability compared to } \\
\text { oral suspension of valsartan }\end{array}$ & $\begin{array}{l}\text { Ahad A et } \\
\text { al., [10] }\end{array}$ \\
\hline
\end{tabular}

\section{d) Delivery of anti-viral drugs}

Jain et al., Developed lamivudine loaded nanoethosomes for effective transdermal delivery and evaluated them for cellular uptake study. Prepared ethanolic formulation showed twenty-five times more transdermal flux in rat skin compared to plain drug solution. Intercellular uptake of ethosomes was five times more in T-lymphoid cell line (MT-2) compared to free drug solution. Later on, production and in-vitro activity evaluation of anti-HSV-1 molecules [acyclovir
(ACY) and N1-beta- D-ribofuranosyl-pyrazole [3, 4d] pyridazin-7(6p-chlorinephenyl)- one nucleoside (N1CP)] loaded nanoethosomes was carried out by Cortesi et al., Nanoethosomes showed controlled release of both molecules predicted through Franz diffusion cell study. Plaque reduction assay in monolayer cultures of Vero cells showed reduction in the ED50 of N1CP indicating increase of its antiviral activity. However, ACY remained more active than N1CP.

Table-4: Anti-viral drugs delivered through nanoethosomes

\begin{tabular}{|c|c|c|c|c|}
\hline Drug & excipients & $\begin{array}{l}\text { Sophisticated } \\
\text { techniques } \\
\text { used }\end{array}$ & Key findings & Author \\
\hline Indinavir & $\begin{array}{l}\text { Soya } \\
\text { phosphatidylcholine, } \\
\text { ethanol }\end{array}$ & $\begin{array}{l}\text { TEM, SEM, } \\
\text { HPLC }\end{array}$ & $\begin{array}{l}\text { Nanoethosomes showed greater permeation of } \\
\text { drug through human cadaver skin along with } \\
\text { shortest lag time compared to conventional } \\
\text { liposomes }\end{array}$ & $\begin{array}{l}\text { Dubey V } \\
\text { et al., } \\
{[11]}\end{array}$ \\
\hline $\begin{array}{l}\text { Acyclovir } \\
(\text { ACV)/ } \\
\text { Acyclovir } \\
\text { Palmitate } \\
(\text { ACV-C16) }\end{array}$ & $\begin{array}{l}\text { Phosphatidyl } \\
\text { choline, Cholesterol, } \\
\text { ethanol }\end{array}$ & $\begin{array}{l}\text { TEM, CLSM, } \\
\text { HPLC }\end{array}$ & $\begin{array}{l}\text { ACV-C16 loaded nanoethosomes showed two } \\
\text { times high drug entrapment and five times } \\
\text { more skin permeation compared to ACV } \\
\text { loaded nanoethosomes }\end{array}$ & $\begin{array}{l}\text { Zhou Y et } \\
\text { al., [12] }\end{array}$ \\
\hline Lopinavir & $\begin{array}{l}\text { Phospholipon } 90 \mathrm{H} \text {, } \\
\text { cholesterol, ethanol }\end{array}$ & $\begin{array}{l}\text { TEM, } \\
\text { Fluorescence } \\
\text { Microscopy, } \\
\text { HPLC }\end{array}$ & $\begin{array}{l}\text { Fluorescence study revealed better disposition } \\
\text { of ethosomal carrier in rat skin compared to } \\
\text { niosomes; but, in-vivo extent of absorption was } \\
\text { high in case of niosomal carrier system }\end{array}$ & $\begin{array}{l}\text { Patel KK } \\
{[13]}\end{array}$ \\
\hline
\end{tabular}

e) Delivery of other bioactive molecules/drugs:

Dayan \& Touitou prepared trihexyphenidyl

$\mathrm{HCl}$ loaded nanoethosomes and evaluated them for transdermal penetration in mice skin using CLSM technique. Nanoethosomes of drug showed 87 and 4.5 times higher transdermal flux compared to conventional 
Ghazala Javeriya Surdana et al., Saudi J Med Pharm Sci, Feb, 2021; 7(2): 91-101

liposomes and hydroethanolic solution respectively; and nanoethosomes also showed high depth of penetration compared to conventional liposomes. Bacitracin loaded nanoethosomes were evaluated by Touitou et al. for intracellular delivery following transdermal route. Results of fluorescent-activated cell sorting (FACS) study showed effective penetration of nanoethosomes through cellular membrane with the release of entrapped bacitracin within the cells. Later on, Dubey et al., evaluated transdermal potential of melatonin loaded nanoethosomes in human cadaver skin and compared them with conventional liposomes. Results of FT-IR studies revealed high mobility of skin lipids after application of nanoethosomes compared to liposomes; and, nanoethosomes also showed penetration up to 240 $\mu \mathrm{m}$ in human cadaver skin.

Table-5: Nanoethosomes for delivery of various types of drugs

\begin{tabular}{|c|c|c|c|c|}
\hline Drug & Excipients & $\begin{array}{l}\text { Sophisticated } \\
\text { techniques used }\end{array}$ & Key findings & Author \\
\hline $\begin{array}{l}\text { 5-Amino } \\
\text { levulinicAcid } \\
\text { (ALA) }\end{array}$ & $\begin{array}{l}\text { Phosphatidyl } \\
\text { ethanolamine, } \\
\text { ethanol }\end{array}$ & $\begin{array}{l}\text { Colorimetry, } \\
\text { CLSM, } \\
\text { HPLC }\end{array}$ & $\begin{array}{l}\text { CLSM study showed depth of penetration } \\
\text { of nanoethosomes upto } 80 \mu \mathrm{m} \text { in murine } \\
\text { skin and penetration studies showed } 26 \\
\text { folds increase in transdermal flux of } \\
\text { Nanoethosomes compared to plain ALA } \\
\text { solution }\end{array}$ & $\begin{array}{l}\text { Fang YP } \\
\text { et.al }^{14}\end{array}$ \\
\hline Paclitaxel & $\begin{array}{l}\text { Phospholipon } \\
\text { 90G, Absolute } \\
\text { ethanol, }\end{array}$ & $\begin{array}{l}\text { HPLC, TEM, } \\
\text { Cell cycle analysis } \\
\text { and apoptotic } \\
\text { determination }\end{array}$ & $\begin{array}{l}\text { Paclitaxel loaded nanoethosomes showed } \\
\text { improved penetration capacity through } \\
\text { stratum } \\
\text { corneum epidermal membrane model and } \\
\text { increased anti-proliferative activity in } \\
\text { squamous cell carcinoma model as } \\
\text { compared to the free drug solution }\end{array}$ & $\begin{array}{l}\text { Paolino D } \\
\text { et.al }^{15}\end{array}$ \\
\hline Tacrolimus & $\begin{array}{l}\text { Lipoid S 100, } \\
\text { Absolute ethanol, } \\
\text { Cholesterol }\end{array}$ & TEM, HPLC & $\begin{array}{l}\text { Tacrolimus loaded nanoethosomes showed } \\
\text { higher encapsulation efficiency, lower } \\
\text { vesicle size, and skin penetration compared } \\
\text { to conventional liposomes with cholesterol }\end{array}$ & Li G $e^{2} a l^{16}$ \\
\hline $\begin{array}{l}\text { Testosterone } \\
\text { Propionate }\end{array}$ & $\begin{array}{l}\text { Soybean } \\
\text { phosphatidyl } \\
\text { choline (PC), } \\
\text { ethanol, } \\
\text { cholesterol }\end{array}$ & $\begin{array}{l}\text { TEM, DSC, HPLC, } \\
\text { CLSM }\end{array}$ & $\begin{array}{l}\text { Prepared nanoethosomes showed high } \\
\text { transdermal flux of } 37.85 \pm 2.8 \mu \mathrm{g} / \mathrm{cm} / \text { hour } \\
\text { and decreased lag time lag time of } 0.18 \\
\text { hours across mouse skin. Nanoethosomes } \\
\text { penetrated upto } 260 \mu \mathrm{m} \text { in mouse skin }\end{array}$ & $\begin{array}{l}\text { Meng. S. } \\
\text { et.al }^{17}\end{array}$ \\
\hline Apigenin & $\begin{array}{l}\text { Lipoid S 75, } \\
\text { propylene glycol, } \\
\text { ethanol }\end{array}$ & TEM, HPLC & $\begin{array}{l}\text { Apigenin loaded nanoethosomes showed } \\
\text { effective reduction of cyclooxygenase-2 } \\
\text { levels in mouse skin inflammation induced } \\
\text { by ultraviolet B (UVB) light compared to } \\
\text { liposomes/ deformable liposomes }\end{array}$ & $\begin{array}{l}\text { Shen LN } \\
\text { et.al }^{18}\end{array}$ \\
\hline Ropivacaine & $\begin{array}{l}\text { Soybean lecithin, } \\
\text { Cholesterol, } \\
\text { Ethanol }\end{array}$ & $\begin{array}{l}\text { TEM, X-ray } \\
\text { diffraction (wide } \\
\text { angle X-ray } \\
\text { scattering), DSC }\end{array}$ & $\begin{array}{l}\text { Results of ex-vivo permeation studies } \\
\text { showed high and rapid penetration of } \\
\text { nanoethosomes in the skin, and } \\
\text { histopathological studies showed } \\
\text { weakening of the penetration barrier due to } \\
\text { loosening of tight junction of corneocytes } \\
\text { layers by impact of ethosomes }\end{array}$ & $\begin{array}{l}\text { Zhai Y et } \\
\text { al., [19] }\end{array}$ \\
\hline $\begin{array}{l}\text { Vancomycin } \\
\text { hydrochloride }\end{array}$ & $\begin{array}{l}\text { Soya phosphatidyl } \\
\text { choline, } \\
\text { Cholesterol, } \\
\text { Ethanol }\end{array}$ & $\begin{array}{l}\text { Delivery of } \\
\text { ethosomes in } \\
\text { combination with } \\
\text { iontophoresis }\end{array}$ & $\begin{array}{l}\text { Prepared nanoethosomes showed high } \\
\text { electrochemical stability and cathodal } \\
\text { iontophoresis of negatively charged } \\
\text { nanoethosomes showed maximum } \\
\text { transdermal flux }(550 \mu \mathrm{g} / \mathrm{cm} 2 / \mathrm{h}) \text { compared } \\
\text { to ethosomes alone }\end{array}$ & $\begin{array}{l}\text { Mohammed } \\
\text { MI et al., } 20\end{array}$ \\
\hline Vinpocetin & $\begin{array}{l}\text { Phosphatidylcholine, } \\
\text { ethanol, chloroform, } \\
\text { di-ethyl ether, tween- } \\
\text { 80, isopropyl alcohol }\end{array}$ & $\begin{array}{l}\text { TEMCM12, } \\
\text { electron } \\
\text { microscope, } \\
\text { DLS,HPLC, UV }\end{array}$ & $\begin{array}{l}\text { Drugloaded Nanoethosomes show } \\
\text { appropriate size,reasonable EE and higher } \\
\text { drug permeation of Vinpocetin when } \\
\text { compared to control. }\end{array}$ & $\begin{array}{l}\text { A.A } \\
\text { MoghaddaM } \\
\text { et al., [21] }\end{array}$ \\
\hline Meloxicam & $\begin{array}{l}\text { Phospholipon 90G, } \\
\text { ethanol, carbapol } \\
\text { 934,cholesterol, PEG- } \\
\text { 400, tri-ethanolamine. }\end{array}$ & $\begin{array}{l}\text { TEM, DLS, UV } \\
\text { detector }\end{array}$ & $\begin{array}{l}\text { Meloxicam loaded Nanoethosomes have } \\
\text { shown highest transdermal flux in } \\
\text { optimized formulation. The in vivo anti- } \\
\text { inflammatory activity in rats using } \\
\text { carragenan induced rat paw edema showed } \\
\text { higher inhibition of swelling of rat paw } \\
\text { edema by using meloxicam containing } \\
\text { carbopol nanaoethosomes compared with } \\
\text { oral administration. }\end{array}$ & $\begin{array}{l}\text { A. Ahad et } \\
\text { al., [22] }\end{array}$ \\
\hline
\end{tabular}


Ghazala Javeriya Surdana et al., Saudi J Med Pharm Sci, Feb, 2021; 7(2): 91-101

\begin{tabular}{|c|c|c|c|c|}
\hline $\begin{array}{l}\text { Betahistine } \\
\text { hydrochloride }\end{array}$ & $\begin{array}{l}\text { Soya beans } \\
\text { phosphatidylcholine, } \\
\text { propylene glycol, } \\
\text { carbopol } 934, \\
\text { poloxamer } 407\end{array}$ & $\begin{array}{l}\text { DLS, ultra- } \\
\text { centrifugation, } \\
\text { TEM, Zeta sizer }\end{array}$ & $\begin{array}{l}\text { Ethosomal gel of betahistine hydrochloride } \\
\text { has shown minimum vesicle size and drug } \\
\text { release and maximum flux and entrapment } \\
\text { efficiency. BDH ethosomal gel showed } \\
\text { effective, sustained absorption and central } \\
\text { action in decrease food intake and weight } \\
\text { gain compared with control, Placebo and } \\
\text { free Betahistine HCL gel. }\end{array}$ & $\begin{array}{l}\text { El- } \\
\text { Menshawe } \\
\text { et al., [23] }\end{array}$ \\
\hline Tetrandrine & $\begin{array}{l}\text { Phosphatidylcholine, } \\
\text { cholesterol, PEG }\end{array}$ & $\begin{array}{l}\text { DLS, PDI, TEM, } \\
\text { HPLC, Franz } \\
\text { diffusion cell, } \\
\text { Confocal laser } \\
\text { scanning } \\
\text { Microscopy. }\end{array}$ & $\begin{array}{l}\text { Tetrandrine loaded ethosomes were } \\
\text { topically administered in rats and drug level } \\
\text { was too low in plasma with reduce side } \\
\text { effects. }\end{array}$ & $\begin{array}{l}\text { Fan et al., } \\
{[24]}\end{array}$ \\
\hline $\begin{array}{l}\text { Cromoyln } \\
\text { Sodium }\end{array}$ & $\begin{array}{l}\text { Soya } \\
\text { phosphatidylcholine, } \\
\text { Ethanol, Chloroform: } \\
\text { methanol mixture. }\end{array}$ & $\begin{array}{l}\text { SEM, DLS, } \\
\text { Zetasizer, } \\
\text { Ultracentrifugation, } \\
\text { Franz diffusion } \\
\text { cell, FT-IR. }\end{array}$ & $\begin{array}{l}\text { Cromyln sodium entrapped ethanolic } \\
\text { ethosomes showed reasonable entrapment } \\
\text { efficiency, optimized vesical size and better } \\
\text { stability. It also enhanced the skin } \\
\text { permeation cromyln sodium in vitro } \\
\text { through porcine ear skin compared with } \\
\text { liposomes, hydro ethanolic and PBS } \\
\text { solutions. }\end{array}$ & $\begin{array}{l}\text { Rakesh and } \\
\text { Anoop [25] }\end{array}$ \\
\hline Tramadol HCL & $\begin{array}{l}\text { Soyalecithin } \\
\text { /cholesterol, ethanol, } \\
\text { PEG, Disodium } \\
\text { EDTA, Carbopol980 }\end{array}$ & $\begin{array}{l}\text { Ultra shear } \\
\text { homogenization, } \\
\text { digital motic } \\
\text { microscope, } \\
\text { Malveen sizer, } \\
\text { zatasizer, Ultra } \\
\text { centrifugation, } \\
\text { Franz diffusion } \\
\text { cell, U.V- } \\
\text { spectrophotometer. }\end{array}$ & $\begin{array}{l}\text { Tramadol } \mathrm{HCl} \text { ethosomes showed } \\
\text { reasonable EE and optimum vesicle size. It } \\
\text { also shown better in- vitro drug release. }\end{array}$ & $\begin{array}{l}\text { Kulkarni, } \\
\text { Shelke O } \\
{[26]}\end{array}$ \\
\hline Liodocane & $\begin{array}{l}\text { Cholesterol, menthol, } \\
\text { ethanol, diethylether, } \\
\text { phosphatidylcholine. }\end{array}$ & $\begin{array}{l}\text { Confocal Laser } \\
\text { scanning } \\
\text { microscopy, SEM, } \\
\text { HPLC,PDI. }\end{array}$ & $\begin{array}{l}\text { Lidocaine ethosomes showed good } \\
\text { encapsulation efficiency. In-vitro studies } \\
\text { showed higher percentage of drug. }\end{array}$ & $\begin{array}{l}\text { Babaie et } \\
\text { al., [27] }\end{array}$ \\
\hline Propranolol HCL & $\begin{array}{l}\text { Soya beans } \\
\text { phosphatidylcholine, } \\
\text { propylene glycol, } \\
\text { carbopol } 934\end{array}$ & $\begin{array}{l}\text { DLS, PDI, TEM, } \\
\text { HPLC, Franz } \\
\text { diffusion cell, zeta } \\
\text { sizer. }\end{array}$ & $\begin{array}{l}\text { Propranolol HCL have shown reasonable } \\
\text { entrapment efficiency, enhanced } \\
\text { bioavailability when compared to control } \\
\text { gel and conventional tablets. }\end{array}$ & $\begin{array}{l}\text { Menshawe } \\
\text { et al., [28] }\end{array}$ \\
\hline $\begin{array}{l}\text { Cryptotanishinone } \\
\text { (CPT) }\end{array}$ & $\begin{array}{l}\text { Soya bea PC, Oleic } \\
\text { acid, Carbomer 974, } \\
\text { PEG400 }\end{array}$ & $\begin{array}{l}\text { Franz diffusion } \\
\text { cell, TEM, PDI, } \\
\text { DLS, Zeta sizer, } \\
\text { HPLC }\end{array}$ & $\begin{array}{l}\text { CPT loaded ethosomes exhibit low vesicle } \\
\text { size, high CPT loading \&EE. The skin } \\
\text { permeation and deposition of ethosomes } \\
\text { with carbomer gel were higher than } \\
\text { conventional gel. In-vitro study proved that } \\
\text { CPTRG has better anti acne effect than } \\
\text { conventional gel. }\end{array}$ & $\begin{array}{l}\text { Yu et al., } \\
\text { [29] }\end{array}$ \\
\hline
\end{tabular}

\section{CONCLUSION}

The development of ethanol based vesicular carriers like Nanoethosomes is a promising approach for delivery of large, small, soluble as well as insoluble bioactive molecules. Ethanol based carriers have capability to mask both drug related and physiological problems like first pass effect, short half-life, GIT irritation, less penetration, etc. Nanoethosomes have shown high transdermal flux of various bioactive molecules compared to conventional liposomes or hydro alcoholic solution. Improvement in stability is a parameter of consideration for ethanol based carriers as they degrade due to oxidation of lipid/ phospholipid content. For their optimum stability necessary storage condition is at $4-8{ }^{\circ} \mathrm{C}$. Formulation of gel of Ethanolic vesicular carriers may improve their viscosity and hence increase their residence time at the application site like skin. So, ethanolic vesicular carriers have potential applications in the field of nano medicine to deliver drugs having solubility/permeability problems through transdermal route.

\section{REFERENCES}

1. Mishra, K. K., Kaur, C. D., Verma, S., Sahu, A. K., Dash, D. K., Kashyap, P., \& Mishra, S. P. (2019). Transethosomes and nanoethosomes: Recent approach on transdermal drug delivery system. Nanomedicine, 2, 33-54.

2. Kumar, L., Verma, S., Singh, K., Prasad, D. N., \& Jain, A. K. (2016). Ethanol based vesicular carriers 
Ghazala Javeriya Surdana et al., Saudi J Med Pharm Sci, Feb, 2021; 7(2): 91-101

in transdermal drug delivery: nanoethosomes and transethosomes in focus. NanoWorld J, 2(3), 41-51.

3. Maheshwari, R. G., Tekade, R. K., Sharma, P. A., Darwhekar, G., Tyagi, A., Patel, R. P., \& Jain, D. K. (2012). Ethosomes and ultradeformable liposomes for transdermal delivery of clotrimazole: a comparative assessment. Saudi Pharmaceutical Journal, 20(2), 161-170.

4. Verma, P., \& Pathak, K. (2011). Nanosized ethanolic vesicles loaded with econazole nitrate for the treatment of deep fungal infections through topical gel formulation. Nanomedicine: Nanotechnology, Biology and Medicine, 8(2012), 489-496.

5. Akhtar, N., \& Pathak, K. (2012). Cavamax W7 Composite ethosomal gel of Clotrimazole for Improved Topical delivery: Development and Comparision with Ethosomal gel. American Association of Pharmaceutical Scientists, 13(1), 344-355.

6. Chen, J. G., Jiang, Y., \& Yang, Z. (2012). Preparation of triptolide ethosomes. African Journal of Pharmacy and Pharmacology, 6(13), 998-1004.

7. Chourasia, M. K., Kang, L., \& Chan, S. Y. (2011). Nanosized ethosomes bearing ketoprofen for improved transdermal delivery. Results in pharma sciences, 1(1), 60-67.

8. Caddeo, C., Sales, O. D., Valenti, D., Saurí, A. R., Fadda, A. M., \& Manconi, M. (2013). Inhibition of skin inflammation in mice by diclofenac in vesicular carriers: liposomes, ethosomes and PEVs. International journal of pharmaceutics, 443(1-2), 128-136.

9. Touitou, E., Dayan, N., Bergelson, L., Godin, B., \& Eliaz, M. (1999). Ethosomes- novel vesicular carriers for enchanced delivery: characterization and skin penetration properties. Journal of Controlled Release. 65(2000), 403-418.

10. Ahad, A., Aqil, M., Kohli, K., Sultana, Y., \& Mujeeb, M. (2013). Enhanced transdermal delivery of an anti-hypertensive agent via nanoethosomes: Statistical optimization, characterization and pharmacokinetic assessment. International Journal of Pharmaceutics. 443(2013), 26-38.

11. Dubey, V., Mishra, D., Asthana, A., \& Jain, N. K. Transdermal delivery of a pineal hormone: Melatonin via elastic liposomes. Biomaterials. 27(2006):341-3496.

12. Zhou, Y., Wei, Y. H., Zhang, G. Q., \& Wu, X. A. (2010). Synergistic penetration of ethosomes and Lipophilic prodrug on Transdermal delivery of Acyclovir. Archives of Pharmacal research. 33(4), 567-574.

13. Patel, K. K., Kumar, P., \& Thakkar, H. P. (2012). Formulation of niosomal gel for enhanced transdermal Lopinavir delivery and its comparative evaluation with ethosomal gel. American association of pharmaceutical scientists. 13(4):1502-1510.

14. Fang, Y. P., Huang, Y. B., Wu, P. C., \& Tsai, Y. H. (2009). Topical delivery of 5-aminolevulinic acid-encapsulated ethosomes in a hyperproliferative skin animal model using the CLSM technique to evaluate the penetration behavior. European Journal of Pharmaceutics and Biopharmaceutics. 73(2009):391-398.

15. Paolino, D., Celia, C., Trapasso, E., Cilurzo, F., \& Fresta, M. (2012). Paclitaxel-loaded ethosomes: Potential treatment of squamous cell carcinoma, a malignant transformation of actinic keratosis. European Journal of Pharmaceutics and Biopharmaceutics. 81(2012), 102-112.

16. Li, G., Fan, Y., Fan, C., Li, X., Wang, X., Li, M., \& Liu, Y. (2012). Tacrolimus-loaded ethosomes: physicochemical characterization and in vivo evaluation. European journal of pharmaceutics and biopharmaceutics, 82(1), 49-57.

17. Meng, S., Chen, Z., Yang, L., Zhang, W., Liu, D., Guo, J., Guan, Y., \& Li, J. (2013). Enchanced transdermal bioavailability of testosterone propionate via surfactant-modified ethosomes. International Journal of Nanomedicine. 8:30513060 .

18. Shen, L. N., Zhang, Y. T., Wang, Q., Xu, L., \& Feng, N. P. (2013). Enchanced in-vitro and in vivo skin deposition of apigenin delivered using ethosomes. International Journal of Pharmaceutics. 460(2014), 280-288.

19. Zhai, Y., Xu, R., Wang, Y., Liu, J., Wang, Z., \& Zhai, G. (2015). Ethosomes for skin delivery of ropivacaine: preparation, characterization and ex vivo penetration properties. Journal of Liposome Research. 1-9.

20. Mohammed, M. I., Makky, A. M., Teaima, M. H. M., Abdellatif, M., Hamzawy, M. A., \& Khalil, M. A. F. (2015). Transdermal delivery of vancomycin hydrochloride using combination of nanoethosomes and iontophoresis: in vitro and in vivo study. Drug delivery. 1-7.

21. Moghaddam, A. A., Aqil, M., Ahmad, F. J., Ali, M. M., Sultana, Y., \& Ali, A. (2015). Nanoethosomes mediated transdermal delivery of Vinpocetine for management of Alzheimer's Disease. Drug Delivery, 22(8), 1019-1026.

22. Ahad, A., Raish, M., Mohizea, A., Jenoobi, F., \& Alam, M. A. (2014). Enhanced anti-inflammatory activity of carbopol loaded meloxicam nanoethosomes gel. International Journal of Biological Macromolecules. 67(2014):99-104.

23. Menshawe, E. F. S., Ali, A. A., Halawa, A. A., \& El-din, A. G. (2017). A novel transdermal nanoethosomal gel of betahistine dihydrochloride for weight gain control: in-vitro and in-vivo characterization. Drug Design, Development and Therapy. 11:3377-3388. 
24. Fan, C., Li, X., Zhou, Y., Zhao, Y., Ma, S., Li, W., Liu, Y., \& Li, G. (2013). Enhanced Topical Delivery of Tetrandrine by Ethosomes for Treatment of Arthritis. BioMed Research International, 2013, 1-13.

25. Rakesh, R., \& Anoop, K. R. (2012). Formulation and optimization of nano-sized ethosomes for enhanced transdermal delivery of cromolyn sodium. Journal of Pharmacy and Bioallied Sciences, 4(4), 333-339.

26. Shelke, O., \& Kulkarni, A. (2018). A Formulation Development and Evaluation of Nano Ethosomal Gel of Tramadol Hydrochloride. Journal of Nanomedicine \& Nanotechnology, 9(5), 1-6.
27. Babaie, S., Ghanbarzadeh, S., Davaran, S., Kouhsltani, M., \& Hamishekar, H. (2015). Nanoethosomes for delivery of Lidocaine. Advanced Pharmaceutical Bulletin, 5(4): 549-556.

28. Menshawe, F. S., Kharshoum, M. R., \& Sisi, M. A. (2017). Preparation and Optimization of Buccal Propranolol Hydrochloride Nanoethosomal Gel: A Novel Approach for Enhancement of Bioavailability. Journal of Nanomedicine and Nanotechnology, 8(2), 1-9.

29. Yu, Z., Lv, H., Han, G., \& Ma, K. (2016). Ethosomes Loaded with Cryptotanshinone for Acne Treatment through Topical Gel Formulation. PLOS one, 11(7), 1-11. 